society everywhere, and the fact that societies under various titles, but all aiming at the cultivation of the natural sciences, were formed in many of our larger lowns as early as between $1850-60$, and more still of late years.

There is another circumstance worthy of notice, which affords perbaps a clearer illustration of the general interest in the natural sciences, and diligence on the field of the same, than even the rise and progress of the various societies already mentioned. It is the constant increase in the number of scientific periodicals, of which the following are already in circulation, besides the publications of the academy and the three societies of which we have spoken :-

(I) Nature (Természet), which appears every two weeks, and is now in the tenth year of its existence; (2) Polytechnical fournal (Mitessetemi lapok), a monthly periodical for mathematical and technical treatises; (3) Reports of the Meetings of the Society of Physicians and Natniralists in Klausenburg, started in 1876 ; (4) Botanical Papers, a monthly, started in $1877 ;(5)$ Leaves of Natural History, a quarterly periodical, started in 1877 , and edited by the Hungary National Museum. At the end of each volume is a review of the contents, written either in French or German, in order to be understood in foreign countries, and containing either a complete translation or an abstract of all the more important articles in the volume; (6) Magazine of Natural Sciences, a two-monthly periodical, started in 1877 , and edited in Temesvár by the Association of Naturalists of South Hungary.

To recapitulate briefly what has been said, there are in Budapest, besides the department of natural sciences in the Academy, three societies, the object of which is exclusively the cultivation of the natural sciences, and one of which is of dimensions that, considering the total number of inhabitants, are scarcely equalled anywhere in Europe. In other parts of our country we have in all six societies of naturalists, and there are in circulation nine scientific periodicals, not one of which enjoys any aid from the State, all being supported exclusively by the readers.

These societies, however, are not the sources of science, but merely, so to speak, its conducting pipes. The sources of it spring from the collections and laboratories of the universities. The progress made here of late years has also been considerable. Ou: university, which was greatly neglected up to the year 1850, has of late taken such a start forward that its condition of ten years ago is not to be compared to its present state. The number of professors' chairs pertaining to the natural sciences (including those of the University and the Polytechnic of Budapest, and the University of Klausenburg) now amounts to three times what it was previously. The greater part of these chairs are occupied by young professors, who have been educated at foreign universities, under the instruction of the most distinguished men of science. Each one has a respectable sum of money at his disposal for cabinet and laboratory purposes. Separate buildings have been raised and equipped as institutes of natural sciences, such as the Chemical and Physio. logical Institute, connected with the University, which stands under the direction of Prof. Charles Than, and already enjoys a wide-spread renown in Europe. The buildings intended for a clinic are nearly completed, and soon the Institute for Mysics, the Mineralogical and Zoological Institute, and the buildings of the Polytechnic will be raised in their turn. The number of the students of philosophy increases with striking rapidity, and some of the most distinguished of these are yearly sent out to foreign universities at state expense, with a view to their afterwards accepting appointments in their own country.

All these things clearly show that Hungary has within the last ten years made striking progress in the field of natural sciences, so that the distance which separated her in this respect from her western neighbours, has grown palpably less. Would that providence should permit her to continue the work thus begun :

J. M. A.

\section{PUBLISHERS' ANNOUNCEMENTS}

MESSRS. WILliam BrackWOOD AND SoNs announce "The Transvaal of To-day: War, Witchchraft, Sport, and Spoils in South Africa," by Capt. Alfred Aylward, late Commandant, Transvaal Republic. Capt. Aylward commanded the Leydenberg volunteers on the Boers' frontier until the Republic was annexed by the British, and from the prominent part he played in Transvaal politics, as well as from his knowledge of the country and his experience of Kaffir warfare, his book may be expected to throw some light upon questions that are now attracting public attention.

Messrs. Kegan PaUl and Co. announce that they will add to their International Scientific Series in October, a "History of the Growth of the Steam Engine," by R. H Thurston, Professor of Mechanical Engineering in the Stevens Institute of Technology, Brooklyn. The volume will give a history of the discoveries, inventions, and many ingenious experiments that gradually led to the success of the steam engine in the last century, and will be illustrated with fifteen portrait and 148 engravings on wood. This work will be followed speedily by Prof. Huxley's volume on "The Crayfish : an Introduction to the Study of Zoology." Prof. Alexander. Bain's "Education as a Science;" and Dr. H. Charlton Bastian's treatise on "The Brain as an Organ of Mind." Two translations from the French will also be included in the series before Christmas, namely, "The Human Race," by Prof. A. de Quatrefages, and "The Brain and its Functions," by Dr. J. Luys, The same publishers announce "The Geology of Ireland," by G. Henry Kinahan, M.R.I.A., \&c., of Her Majesty's Geological Survey; with numerous illustrations and a geological map of Ireland; to be ready in October. "Etna a History of the Mountain and its Eruptions," with mans and illustrations, by G. F. Rodwell, F.R.A.S., F.C.S. "Flowers and their Unbidden Guests," by Dr. A. Kerner, Professor of Botany in the University of Innsbruck; translation edited by W. Ogle, M.A., M.B.; with illustrations. "Mind in the Lower Animals in Health and Disease," by W. Lunder Lindsay, M.D., F.R.S.E., F.L.S., Hon. Member of the New Zealand Institnte; Vol. I. Mind in Health; Vol. II. Mind in Disease. "History of the Evolution of Man," by Prof. Ernst Haeckel, Author of "The History of Creation ;" two vols., with numerous illustrations. "Gaur: its Ruins and Inscriptions," by the Late John Henry Ravenshaw, B.C.S. ; edited by his Widow; with forty photographic illustrations, and fourteen facsimiles of inscriptions. These three last books will be ready for publication in November.

Messrs. Reeve AND Co. have just published the fourth edition of Bentham's " Handbook of the British Flora." The principal alteration in this edition has been the giving the first place to the Latin names of the genera and species. The attempt made in previous editions to establish an English scientific nomenclature, in imitation of the French and German ones introduced into several standard Continental floras, has, we regret to say, proved a failure.

Messrs. Macmillan and Co, will publish, in the course of the season, the following new books and new editions:-" Sport and Work on the Nepaul Frontier, or Twelve Years' Sporting Reminiscences of an Indigo Planter," by "Maori," with Map and Illustrations ; "Coal, its History and its Uses," by Profs. Green, Miall, Thorpe, Rücker, and Marshail, of the Yorkshire College, Leeds, with numerous Illustrations, 8vo; "Chemistry: a Treatise on," by Profs. Roscoe and Schorlemmer, of the Owens College, Manchester, vol, ii., "Metals," part I, 8vo ; "Gegenbaur's Comparative Anatomy," a Translation revised with Preface by Prof. E. Ray Lankester, F.R.S., with numerous Illustrations, medium 8vo; "A System of Medicine," Edited by J. Russell Reynolds, M.D., F.R.S, vol, v., completing the work; "Modern Realism Examined," by the late Prof. Herbert, Edited by Prof. James M. Hodgson; "Science Lectures at South Kensington," vol, ii., crown 8vo; "The Theory of Sound," by Lord Rayleigh, M.A., F.R.S., vol, iii., 8vo ; "Heat," an Elementary Treatise, by P. G. Tait, Professor of Natural Philosophy at Edinburgh, with numerous illustrations, crown 8vo; "Sound" (NATURE series): a series of simple, entertaining, and inexpensive experiments in the phenomena of sound, for the use of students of every age, by Alfred Marshall Mayer, Professor of Physics in the Stevens Institute of Technology, \&c., \&c. ; "Ismailia" by Sir Samuel W. Baker, Pasha, a narrative of the expedition to Central Africa for the suppression of the slave trade, organised by Ismail, Khedive of Egypt, with maps, portraits, and numerous illustrations by Zwecker and Durand, new and cheaper edition, one vol., crown 8vo; "A Ramble Round the World," by M. le Baron de Hiubner, formerly Ambassador and Minister, translated by Lady Herbert, new and cheaper edition with numerous illustra. tions, crown 8vo. 